\title{
BMJ Open Mode of delivery at birth and the metabolic syndrome in midlife: the role of the birth environment in a prospective birth cohort study
}

\author{
Béatrice Bouhanick, ${ }^{1,2}$ Virginie Ehlinger, ${ }^{2,3}$ Cyrille Delpierre, ${ }^{2,3}$ \\ Bernard Chamontin, ${ }^{1,2}$ Thierry Lang, ${ }^{2,3,4}$ Michelle Kelly-Irving ${ }^{2,3}$
}

To cite: Bouhanick B, Ehlinger V, Delpierre C, et al. Mode of delivery at birth and the metabolic syndrome in midlife: the role of the birth environment in a prospective birth cohort study. BMJ Open 2014;4:e005031.

doi:10.1136/bmjopen-2014005031

- Prepublication history and additional material is available. To view please visit the journal (http://dx.doi.org/ 10.1136/bmjopen-2014005031)

$\mathrm{BB}$ and VE contributed equally.

Received 10 February 2014 Revised 9 April 2014 Accepted 23 April 2014

CrossMark

For numbered affiliations see end of article.

Correspondence to Dr Béatrice Bouhanick; duly-bouhanick.b@ chu-toulouse.fr

\section{ABSTRACT}

Objectives: The aim of this study is to examine the hypothesis that mode of delivery at birth may be associated with metabolic disorders in adult midlife.

Setting: Population cohort study

Participants: The National Child Development Study consists of individuals born during 1 week in 1958 in Great Britain. Respondents with biomedical data on the metabolic syndrome at age 45 were included.

Outcome measure: The metabolic syndrome was defined based on the National Cholesterol Education Program Adult Treatment Panel (NCEP-ATP) III classification.

Results: 7156 were born naturally; among the caesarean births, 106 were non-elective and 85 were elective caesareans. The metabolic syndrome is present in $37.7 \%$ of those born by non-elective caesareans, $25.9 \%$ of those born by elective caesarean and $27.5 \%$ of those born by vaginal delivery. In a multivariate logistic regression model adjusted for antenatal factors, birth history, mother's characteristics and the socioeconomic environment at birth, only birth by non-elective caesarean remained associated with the metabolic syndrome in adulthood compared with vaginal delivery (OR $1.51,95 \% \mathrm{Cl} 1.00$ to 2.30$)$. Mother's obesity (OR $1.61,95 \% \mathrm{Cl} 1.12$ to 2.34 ) and low maternal education level (OR 1.47, $95 \% \mathrm{Cl} 1.30$ to 1.67) were also independently associated with midlife metabolic syndrome.

Conclusions: Birth by non-elective caesarean in 1958 may be associated with metabolic syndrome in adulthood after adjusting for prior confounding factors. We suggest that the birth context of emergency caesareans in 1958 is suggestive of a 'fetal stress' mechanism affecting health across the lifecourse.

\section{INTRODUCTION}

In recent years, a number of studies have suggested that the mode of delivery at birth may be associated with obesity and metabolic disruption across the lifecourse. This stems from epidemiological research showing

\section{Strengths and limitations of this study}

Being born by emergency caesarean in 1958 may be associated with the metabolic syndrome in midlife.

- Mode of delivery may be a proxy for the birth environment and contextually variable clinical practices.

- Given the possible context of emergency caesareans in 1958, a 'fetal stress' hypothesis is suggested for the subsequent association with the metabolic syndrome.

- It is possible that an unknown confounding factor during early life was omitted from the analyses, which might explain the differences observed in MS outcome between the mode of delivery groups.

associations between birth by caesarean section and obesity in childhood. ${ }^{1}{ }^{2}$ Such associations deserve further investigation given, on the one hand, the dramatic increases in caesarean sections in recent decades, from $21 \%$ in 1996 to $32 \%$ in $2007,{ }^{3}$ and on the other hand, the burden of morbidity due to metabolic diseases. ${ }^{4}$ The hypothesised mechanism for this association involves the colonisation of the gut microbiota. ${ }^{5}$

Animal models have shown that modifications to rat gut microbiota have led to metabolic disruptions and ultimately obesity in affected animals. ${ }^{6}$ The gut microbiota is a potential source of inflammatory molecules that may contribute to metabolic diseases. ${ }^{78}$ This possible link between gut microbiota and metabolic disruptions is relevant to mode of delivery at birth due to the colonisation of the gut flora that occurs when the baby ingests maternal vaginal flora as she/he passes along the birth canal. If a caesarean section is carried out to deliver the baby, this phase of birth is skipped, and the baby is not 
exposed to the vaginal flora. The colonisation of their digestive tract therefore occurs differently to a baby which was delivered naturally. ${ }^{9-11}$ Recent reports have linked differences in infant gut microbiota with subsequent obesity. ${ }^{12}$

To explore the hypothesis that mode of delivery may be associated with metabolic disruptions, it is important to consider the context surrounding the pregnancy, birth and, where possible, variations in the mode of delivery. Caesarean sections have become part of routine practice in maternity wards, often planned well in advance in the case of at-risk pregnancies. ${ }^{13}$ However, the practice of caesareans was not so commonplace up to three decades ago, and individuals born under rather different practices and clinical conditions are now in their 40s and 50s. In this paper, we use a prospective birth cohort study of individuals born in 1958 to explore the possible association between mode of delivery at birth and the occurrence of the metabolic syndrome (MS) in midlife (45 years) under different contextual circumstances surrounding birth. Study participants delivered naturally, born via planned caesarean and via unplanned caesarean will be compared in terms of their MS profile at the age of 45 using available biomedical data from a birth cohort study.

\section{METHODS}

\section{Sample and participants}

This study used data from the 1958 National Child Development Study (NCDS) which included all births during 1 week in $1958(n=18558)$ in Great Britain. Subsequent data collections were carried out on cohort members aged 7, 11, 16, 23, 33, 42, 46 and 50. The NCDS has been described in detail elsewhere. ${ }^{14} \mathrm{~A}$ biomedical survey (9377 cohort members participating) was conducted when participants were aged 44-46 years (figure 1).

\section{Ethics}

Written informed consent was obtained from the cohort member's parents for childhood measurements.. NCDS data are open access datasets available to non-profit research organisations.

\section{Outcome measure}

MS was defined using NCEP-ATP III (National Cholesterol Education Program Adult Treatment Panel III) clinical criteria, except for plasma glucose, which was not recorded and replaced by glycated haemoglobin $(\mathrm{HbA} 1 \mathrm{c}) \geq 6.5 \% .^{15}$

\section{Exposure variable}

Mode of delivery was categorised into three groups: emergency caesarean, elective caesarean or vaginal delivery.

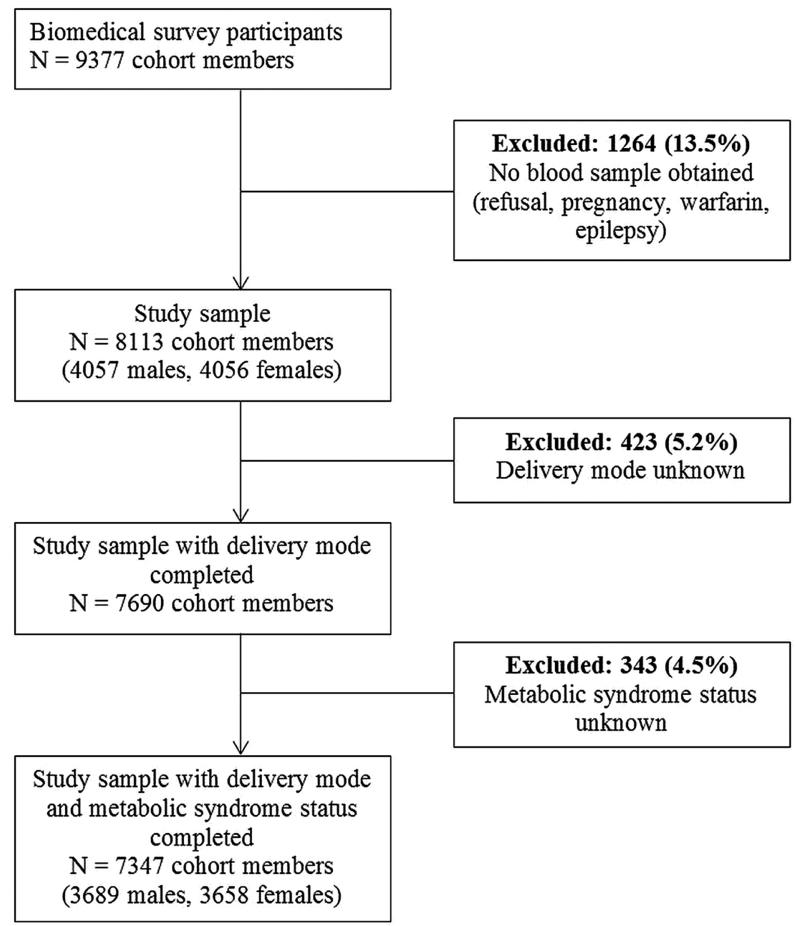

Figure 1 Flow chart showing the sample selection.

\section{Covariates}

The variables taken into account covered four areas:

1. Mother's socioeconomic and health characteristics before the current pregnancy: mother's educational level (left school before/after minimum leaving age); household overcrowding (people per room); mother's self-reported pre-pregnancy weight and her height measured after the birth were used to construct the mother's pre-pregnancy body mass index (BMI) (weight in $\left.\mathrm{kg} /(\text { height in } \mathrm{m})^{2}\right)$. Since some mothers were younger than 18 years of age, agespecific BMI cut-offs were used in order to categorise BMI into four groups: thinness, normal, overweight and obese (corresponding to the cut-offs of $<18.5$, $18.5-24.9,25-29.9$ and $\geq 30 \mathrm{~kg} / \mathrm{m}^{2}$ for adults, respectively). Mother's parity in 1958, including miscarriages after 28 weeks, was also extracted.

2. Previous pregnancy complications: previous pregnancy problems (yes/no), constructed based on whether the mother had previously had: an abortion or ectopic pregnancy, previous stillbirths, a previous neonatal death or other previous pregnancy complications.

3. Information on the current pregnancy: maternal age at birth; whether the mother smoked during pregnancy beyond the fourth month (yes/ no); abnormality during pregnancy (none/at least one abnormality including: antepartum haemorrhage, placenta praevia, vaginal bleeding and other abnormalities); hypertensive pathology (none/hypertension/toxaemia/proteinuria/eclampsia) and total number of antenatal visits $(<5,5-9$ and $>9$ visits $)$. 
4. Details of the labour and birth: time elapsed since rupture of membranes ( $\geq 12 \mathrm{~h}$ before delivery ie, premature rupture of the membranes $(\mathrm{PROM}) /<12 \mathrm{~h}$ before delivery): whether labour was induced (yes/ no); birthweight for gestation $(<10$ th centile, $10-90$ th centile, $>90$ th centile); gestational age was calculated as the duration between the first day of the mother's last menstrual period and childbirth, and categorised into groups $(<38,38,39-41$ and $>41$ weeks $)$.

\section{Statistical analyses}

We first determined the prevalence of MS, and used the $\chi^{2}$ test to assess whether this prevalence differed by mode of delivery. The covariates were summarised as frequencies and percentages for categorical variables, means and SDs for continuous variables. $\chi^{2}$ or Fisher's exact tests were performed in order to compare the sample characteristics according to the exposure or the outcome. Comparisons of means by mode of delivery category were computed using analysis of variance, whereas the comparisons of means by MS status were carried out using the Student $\mathrm{t}$ test, after validating assumptions of normality and homoscedasticity.

Unadjusted and adjusted logistic regression models were carried out to explore the relationship between MS and mode of delivery. Complete case and multiple imputation analyses were conducted.

To control for possible bias due to missing data, we imputed data for covariates with missing data using the multiple imputation program ICE in STATA V.11. ${ }^{16}$ For more details, see the online supplementary data.

\section{RESULTS}

Among 7347 observations, the prevalence of MS was $27.6 \%$ ( $36.6 \%$ for men, $18.6 \%$ for women, $\mathrm{p}<0.001$ ). In total, 191 cohort members $(2.6 \%$ of the sample) were delivered by caesarean section (106 emergency, 85 elective caesarean sections). The prevalence of MS in the emergency and in the elective caesarean were $37.7 \%$ (95\% CI $28.5 \%$ to $47.0 \%$ ) and $25.9 \%$ (95\% CI $16.5 \%$ to $35.3 \%)$, respectively. The estimated prevalence of MS was $27.5 \%$ (95\% CI $27.2 \%$ to $27.8 \%$ ) within the vaginal delivery group, $37.7 \%$ (95\% CI $34.9 \%$ to $40.5 \%$ ) within the emergency caesarean group and $25.9 \%$ (95\% CI $23.1 \%$ to $28.7 \%$ ) within the elective caesarean group (global $\chi^{2}$ test $\mathrm{p}=0.061$ ).

Sample characteristics according to mode of delivery are reported in table 1. Several maternal characteristics, parity, problems during previous pregnancies, abnormalities during the current pregnancy, induced labour, PROM and gestational age were highly associated with the cohort member's mode of delivery at birth $(p<0.001)$. Specifically, older maternal age at birth, nulliparous mothers, induced labour, PROM and overdue birth ( $>41$ weeks) were more frequent in the emergency caesarean section group. On the other hand, problems during previous pregnancies (past stillbirth and neonatal deaths and past complications of pregnancy), abnormality during pregnancy and premature birth ( $<38$ weeks) were more frequent in the elective caesarean delivery group. Previous caesarean was also a strong predictor of elective caesarean delivery (data not shown).

Table 2 shows the relationships between mode of delivery, the covariates and MS. A low maternal level of education, smoking after the fourth month of pregnancy and maternal obesity were associated with a higher prevalence of MS. We also found significant links between MS and the following: hypertensive pathology, induced labour and PROM.

In table 3, we report unadjusted (model 1) and adjusted (model 2) ORs resulting from the final logistic regression model. Model 2 is adjusted for the effects of the cohort member's gender, maternal age, mother's educational level, smoking habits during pregnancy, BMI, parity, problems with previous pregnancies, hypertensive pathology during pregnancy, birthweight, gestational age, induction of labour and PROM (table 3model 2). The results show that emergency caesarean delivery was associated with an increased proportion of MS compared with vaginal delivery $(\mathrm{OR}=1.51, \mathrm{p}=0.05$ results from imputed data).

An increased probability of having MS in midlife was also associated with: being male, a lower maternal education level, maternal smoking in pregnancy, maternal prepregnancy obesity and maternal hypertensive pathology during pregnancy. Respondents whose mothers were younger at the time of their birth were less likely to have MS in midadulthood.

\section{DISCUSSION}

These analyses show that differences in the prevalence of MS at 45 years may be associated with the mode of delivery at birth, after controlling for possible confounders. However, the association observed is not for respondents born by caesarean section overall versus those born vaginally. Rather, emergency caesarean delivery remained associated with an increased risk of having MS in midlife compared with individuals born vaginally. These findings differ from studies carried out on cohorts of individuals born recently, showing that caesarean section per se is a risk for metabolic disorders via the gut microbiota hypothesis. ${ }^{11}$ The results from our study using data from births in 1958 suggest that mode of delivery may be a proxy variable for qualities in the birth environment that may have had long-term implications for cohort members' health. We suggest that in 1958, caesarean sections were a rare phenomenon (2.6\% prevalence), carried out electively in the case of high-risk pregnancies. When caesareans were emergency, we hypothesise that the birth context was most likely stressful, resulting in an emergency caesarean section. The stressful nature of the birth may play an 
Table 1 Description of covariates in terms of mode of delivery

\begin{tabular}{|c|c|c|c|c|}
\hline Variable & $\begin{array}{l}\text { Vaginal delivery } \\
(\mathrm{N}=7156) \\
\mathrm{n}(\%)\end{array}$ & $\begin{array}{l}\text { Emergency caesarean } \\
(\mathrm{N}=106) \\
\mathrm{n}(\%)\end{array}$ & $\begin{array}{l}\text { Elective caesarean } \\
(\mathrm{N}=85) \\
\mathrm{n}(\%)\end{array}$ & $\begin{array}{l}p \text { Value } \\
\chi^{2}\end{array}$ \\
\hline Cohort member's gender & & & & 0.156 \\
\hline Male & $3580(50.0)$ & $61(57.6)$ & $48(56.5)$ & \\
\hline Female & $3576(50.0)$ & $45(42.4)$ & 37 (43.5) & \\
\hline Maternal age, years & & & & $<0.001 \mathrm{~F}$ \\
\hline$<18$ & $69(1.0)$ & $0(0.0)$ & $0(0.0)$ & \\
\hline $18-35$ & $6414(89.7)$ & $87(82.1)$ & $63(74.1)$ & \\
\hline$>35$ & $668(9.3)$ & 19 (17.9) & $22(25.9)$ & \\
\hline Mother's educational level & & & & 0.045 \\
\hline Low & $5224(73.2)$ & $69(65.7)$ & $54(64.3)$ & \\
\hline High & $1913(26.8)$ & $36(34.2)$ & $30(35.7)$ & \\
\hline Overcrowding & & & & 0.049 \\
\hline 1-1.5 people/room & $6140(88.1)$ & $96(96.0)$ & $73(89.0)$ & \\
\hline$\geq 1.5$ people/room & $832(11.9)$ & $4(4.0)$ & $9(11.0)$ & \\
\hline Smoking after the fourth month of pregnancy & & & & 0.589 \\
\hline No & 4766 (67.4) & $74(71.8)$ & $55(65.5)$ & \\
\hline Yes & 2303 (32.6) & $29(28.2)$ & $29(34.5)$ & \\
\hline Maternal BMI before pregnancy & & & & $0.075 \mathrm{~F}$ \\
\hline Underweight & $305(4.5)$ & $3(3.1)$ & $4(5.3)$ & \\
\hline Normal weight & 4915 (72.6) & $69(71.1)$ & $48(63.2)$ & \\
\hline Overweight & $1293(19.1)$ & $18(18.6)$ & $16(21.0)$ & \\
\hline Obesity & $262(3.8)$ & $7(7.2)$ & $8(10.5)$ & \\
\hline Parity & & & & $<0.001$ \\
\hline Nulliparous & $2636(36.9)$ & $67(63.2)$ & $20(23.5)$ & \\
\hline 1 previous pregnancy & 2269 (31.7) & $20(18.9)$ & $32(37.7)$ & \\
\hline$\geq 2$ previous pregnancies & $2250(31.4)$ & 19 (17.9) & $33(38.8)$ & \\
\hline Problems with previous pregnancies & & & & $<0.001$ \\
\hline No & $5638(78.9)$ & $73(68.9)$ & $36(42.4)$ & \\
\hline Yes & $1504(21.1)$ & $33(31.1)$ & 49 (57.6) & \\
\hline Hypertensive pathology during pregnancy & & & & 0.002 \\
\hline No & 4654 (68.3) & $59(62.1)$ & $41(51.3)$ & \\
\hline Yes & $2164(31.7)$ & $36(37.9)$ & $39(48.7)$ & \\
\hline Abnormality during pregnancy & & & & $<0.001$ \\
\hline No & $5358(74.9)$ & $50(47.2)$ & $23(27.1)$ & \\
\hline Yes & $1794(25.1)$ & $56(52.8)$ & $62(72.9)$ & \\
\hline Total number of antenatal visits & & & & $0.240 \mathrm{~F}$ \\
\hline$<5$ & $295(4.2)$ & $2(1.9)$ & $4(4.8)$ & \\
\hline $5-9$ visits & $1912(27.1)$ & $25(24.3)$ & $30(36.1)$ & \\
\hline$>9$ & $4859(68.7)$ & $76(73.8)$ & 49 (59.2) & \\
\hline Birthweight & & & & 0.392 \\
\hline$<10$ th centile & $525(8.4)$ & $4(4.8)$ & $6(8.5)$ & \\
\hline 10-90th centile & $5094(81.7)$ & $67(79.8)$ & $59(83.1)$ & \\
\hline >90th centile & $619(9.9)$ & $13(15.4)$ & $6(8.4)$ & \\
\hline Gestational age, weeks & & & & $<0.001$ \\
\hline$<38$ & $770(9.8)$ & $14(12.1)$ & $25(25.5)$ & \\
\hline 38 & $610(7.8)$ & 15 (12.9) & $23(23.5)$ & \\
\hline 39-41 & $5504(70.4)$ & 59 (50.9) & 45 (45.9) & \\
\hline$>41$ & 935 (12.0) & $28(24.1)$ & $5(5.1)$ & \\
\hline Whether labour induced & & & & $<0.001$ \\
\hline No & $6242(87.2)$ & $68(64.2)$ & 81 (95.3) & \\
\hline Yes & 914 (12.8) & $38(35.8)$ & $4(4.7)$ & \\
\hline PROM >12h & & & & $<0.001$ \\
\hline No & $5599(85.0)$ & $55(55.6)$ & $83(100.0)$ & \\
\hline Yes & $985(15.0)$ & $44(44.4)$ & $0(0.0)$ & \\
\hline
\end{tabular}


important part in the observed association between emergency caesarean births and MS in midlife.

Factors occurring prior to and at the time of birth may contribute to the association between emergency caesareans and the subsequent development of MS.
Based on the information from the NCDS, the women who had non-elective caesareans in 1958 were more likely to be overdue, to have had an induced labour and to have experienced rupture of the membranes more than $12 \mathrm{~h}$ before the birth. Such births seem to have

Table 2 Characteristics of mothers and cohort members before pregnancy, during pregnancy and labour, and at birth in terms of the metabolic syndrome at age $44-46$ years $(n=7347)$

\begin{tabular}{|c|c|c|c|}
\hline \multirow[b]{2}{*}{ Variable } & \multicolumn{2}{|c|}{ Metabolic syndrome } & \multirow[b]{2}{*}{$\begin{array}{l}\text { p Value } \\
\chi^{2}\end{array}$} \\
\hline & $\begin{array}{l}\text { No } \\
(\mathrm{N}=5317) \\
\mathrm{n}(\%)\end{array}$ & $\begin{array}{l}\text { Yes } \\
(\mathrm{N}=2030) \\
\mathrm{n}(\%)\end{array}$ & \\
\hline Mode of delivery & & & 0.061 \\
\hline Vaginal & $5188(97.6)$ & $1968(97.0)$ & \\
\hline Emergency caesarean & $66(1.2)$ & $40(2.0)$ & \\
\hline Elective caesarean & $63(1.2)$ & $22(1.1)$ & \\
\hline Cohort member's gender & & & $<0.001$ \\
\hline Male & $2339(44.0)$ & $1350(66.5)$ & \\
\hline Female & $2978(56.0)$ & $680(33.5)$ & \\
\hline Maternal age, years & & & 0.166 \\
\hline$<18$ & $44(0.8)$ & $25(1.2)$ & \\
\hline 18-35 & $4743(89.3)$ & $1821(89.7)$ & \\
\hline$>35$ & $525(9.9)$ & $184(9.1)$ & \\
\hline Mother's educational level & & & $<0.001$ \\
\hline Low & $3751(70.8)$ & $1596(78.8)$ & \\
\hline High & $1549(29.2)$ & $430(21.2)$ & \\
\hline Overcrowding & & & 0.330 \\
\hline 1-1.5 people/room & $4573(88.4)$ & $1736(87.6)$ & \\
\hline$\geq 1.5$ people/room & 599 (11.6) & $246(12.4)$ & \\
\hline Smoking after the fourth month of pregnancy & & & $<0.001$ \\
\hline No & 3606 (3606) & $1289(64.2)$ & \\
\hline Yes & $1643(31.3)$ & $718(35.8)$ & \\
\hline Maternal BMI before pregnancy & & & $<0.001$ \\
\hline Underweight & $230(4.6)$ & $82(4.3)$ & \\
\hline Normal weight & $3738(74.2)$ & $1294(67.9)$ & \\
\hline Overweight & $902(17.9)$ & 425 (22.3) & \\
\hline Obesity & $171(3.4)$ & $106(5.6)$ & \\
\hline Parity & & & 0.089 \\
\hline Nulliparous & $1938(36.5)$ & $785(38.7)$ & \\
\hline 1 previous pregnancy & 1716 (32.3) & $605(29.8)$ & \\
\hline$\geq 2$ previous pregnancies & $1662(31.3)$ & $640(31.5)$ & \\
\hline Problems with previous pregnancies & & & 0.771 \\
\hline No & $4163(78.5)$ & $1584(78.2)$ & \\
\hline Yes & $1143(21.5)$ & $443(21.8)$ & \\
\hline Hypertensive pathology during pregnancy & & & $<0.001$ \\
\hline No & $3498(69.2)$ & $1256(64.7)$ & \\
\hline Yes & $1555(30.8)$ & $684(35.3)$ & \\
\hline Abnormality during pregnancy & & & 0.554 \\
\hline No & $3941(74.2)$ & $1490(73.5)$ & \\
\hline Yes & $1374(25.9)$ & $538(26.5)$ & \\
\hline Total number of antenatal visits & & & 0.163 \\
\hline$<5$ & $230(4.4)$ & $71(3.5)$ & \\
\hline $5-9$ visits & $1436(27.4)$ & $531(26.5)$ & \\
\hline$>9$ & 3579 (68.2) & $1405(70.0)$ & \\
\hline Birthweight & & & 0.252 \\
\hline$<10$ th centile & $374(8.0)$ & $161(9.3)$ & \\
\hline 10-90th centile & 3807 (81.8) & $1413(81.2)$ & \\
\hline >90th centile & $472(10.4)$ & $166(9.5)$ & \\
\hline
\end{tabular}


Table 2 Continued

\begin{tabular}{|c|c|c|c|}
\hline \multirow[b]{2}{*}{ Variable } & \multicolumn{2}{|c|}{ Metabolic syndrome } & \multirow[b]{2}{*}{$\begin{array}{l}p \text { Value } \\
\chi^{2}\end{array}$} \\
\hline & $\begin{array}{l}\text { No } \\
(\mathrm{N}=5317) \\
\mathrm{n}(\%)\end{array}$ & $\begin{array}{l}\text { Yes } \\
(\mathrm{N}=2030) \\
n(\%)\end{array}$ & \\
\hline Gestational age, weeks & & & 0.268 \\
\hline$<38$ & $463(9.6)$ & $196(10.8)$ & \\
\hline 38 & $383(7.9)$ & $157(8.6)$ & \\
\hline $39-41$ & $3414(70.7)$ & $1246(68.4)$ & \\
\hline$>41$ & $567(11.8)$ & $224(12.3)$ & \\
\hline Whether labour induced & & & 0.002 \\
\hline No & $4666(87.8)$ & $1725(85.0)$ & \\
\hline Yes & $651(12.2)$ & 305 (15.0) & \\
\hline PROM> $12 \mathrm{~h}$ & & & 0.003 \\
\hline No & $4203(85.6)$ & $1534(82.7)$ & \\
\hline Yes & 708 (14.4) & $321(17.3)$ & \\
\hline
\end{tabular}

gradually become emergency situations presumably after a long labour, with $97 \%$ of babies born thus described as having experienced 'fetal distress' by the duty midwife (data not shown). Abnormalities occurring at birth as indicated by an induced labour or a late delivery were more frequent in the emergency caesarean section group. Historically, the main reasons given by clinicians for carrying out caesareans, other than having previously had a caesarean, are the relatively undefined concepts of 'fetal distress', 'failure to progress' during labour and breech presentations. ${ }^{17}$ Given the rare occurrence of caesareans in the late 1950 s, we can only speculate that the conditions surrounding a labour ending in an emergency caesarean were likely to have been fraught and stressful for those involved, not least for the baby. We put forward a fetal stress hypothesis, whereby babies born by emergency caesarean were subject to physiological stress and possibly their mother's psychological stress and its consequences in the postnatal period. Such a context of stress may have affected the baby's physiological and psychological stress responses thereafter. Early life stress has been associated with physiological alterations leading individuals along negative health trajectories. ${ }^{18}{ }^{19}$ Furthermore, in later life, a stressful environment, such as job stress, has been associated with a greater prevalence of MS. ${ }^{20}$

The colonisation of the gut microbiota during vaginal births, and the lack thereof during caesarean births, has been put forward as a hypothesis for links observed in previous studies on caesarean delivery and metabolic disorders in childhood or adulthood. ${ }^{1}$ Some authors have reported that mode of delivery is associated with a differential colonisation of the gut flora. Higher proportions of bacteria from the Firmicutes group, and a lower frequency of members of the Bacteroidetes group, have been observed in children delivered by caesarean section compared with those born vaginally. ${ }^{11}$ Moreover, infants born by caesarean delivery were significantly less often colonised with bacteria of the Bacteroides fragilis group than vaginally delivered infants, and these subgroups represent the majority of the microbiota found in the adult gut. ${ }^{521}$

To support this hypothesis, we would have observed differences in the prevalence of MS between caesareans per se and vaginal birth; however, this was not the case. No association was observed between overall caesarean section in 1958 and MS in midlife. Differences between the gut microbiota of individuals born by emergency caesarean section versus those delivered vaginally but not in those born by elective caesarean section have been reported. A lower frequency of Escherichia-Shigella has been observed in other studies for those born by emergency caesarean. ${ }^{22}$ We cannot exclude that babies born by emergency caesarean were more likely to experience a prolonged exposure to vaginal bacteria and possibly to infectious pathogens, due to PROM (44\% of emergency caesareans exposed to PROM vs $15 \%$ vaginal delivery and $0 \%$ elective caesareans). Mode of delivery has previously been associated with childhood obesity at 3 years of age, and the authors postulated that a longer exposure to bacterial flora could be a mechanism involved in childhood obesity. ${ }^{1}$

We reported that maternal pre-pregnancy obesity was associated with an increased probability of having MS at the modal age of 45 years. Previous work has shown that children exposed to maternal obesity in early life had a twofold increased risk of developing MS, with a trend towards a higher incidence of insulin resistance. ${ }^{23}$ Offspring exposed to maternal hyperglycaemia during their intrauterine development were also more prone to metabolic disorders in young adulthood leading to insulin resistance. ${ }^{24} 25$ Different paths of childhood growth with smaller gains in BMI during infancy could precede the development of MS or hypertension. ${ }^{26} 27$

There are a number of limitations to our study. The definition of MS proposed by different organisations has 
Table 3 Unadjusted and adjusted logistic regression models showing relationship between mode of delivery and the metabolic syndrome in midlife: complete case analyses and analyses using multiply imputed data

\begin{tabular}{ll} 
Complete case & Multiple imputations \\
OR $(95 \% \mathrm{Cl})$ & OR $(95 \% \mathrm{CI})$ \\
\hline
\end{tabular}

\begin{tabular}{|c|c|c|}
\hline Model 1: unadjusted & & \\
\hline Mode of delivery & & \\
\hline Vaginal (ref) & & \\
\hline Emergency caesarean & $1.60(1.42 \text { to } 1.80)^{\star \star \star}$ & $1.60(1.08 \text { to } 2.37)^{*}$ \\
\hline Elective caesarean & $0.92(0.74$ to 1.07$)$ & $0.92(0.57$ to 1.50$)$ \\
\hline Model 2: adjusted† & & \\
\hline Mode of delivery & & \\
\hline Vaginal (ref) & & \\
\hline Emergency caesarean & $2.18(1.28 \text { to } 3.71)^{\star *}$ & $1.51(1.00 \text { to } 2.30)^{\star}$ \\
\hline Elective caesarean & $1.00(0.53$ to 1.91$)$ & $0.93(0.56$ to 1.56$)$ \\
\hline Cohort member's gender & & \\
\hline Female (ref) & & \\
\hline Male & $2.48(2.18 \text { to } 2.82)^{\star \star *}$ & $2.58(2.31 \text { to } 2.87)^{\star \star \star}$ \\
\hline Maternal age & & \\
\hline Years & $0.98(0.97 \text { to } 0.99)^{* *}$ & $0.98(0.97 \text { to } 0.99)^{\star * *}$ \\
\hline Mother's educational level & & \\
\hline High (ref) & & \\
\hline Low & $1.48(1.27 \text { to } 1.73)^{\star \star \star}$ & $1.47(1.30 \text { to } 1.67)^{\star \star \star}$ \\
\hline Smoking after the fourth $\mathrm{m}$ & & \\
\hline No (ref) & & \\
\hline Yes & $1.28(1.11 \text { to } 1.46)^{\star *}$ & $1.24(1.10 \text { to } 1.39)^{\star \star \star}$ \\
\hline Maternal BMI before pregr & & \\
\hline Normal weight (ref) & & \\
\hline Underweight & 0.87 (0.64 to 1.20$)$ & $0.97(0.74$ to 1.27$)$ \\
\hline Overweight & 1.19 (0.85 to 1.67$)$ & $1.33(0.99$ to 1.78$)$ \\
\hline Obesity & 1.45 (0.94 to 2.24$)$ & $1.61(1.12 \text { to } 2.34)^{\star \star}$ \\
\hline Hypertensive pathology du & & \\
\hline No (ref) & & \\
\hline Yes & $1.24(1.08 \text { to } 1.43)^{\star *}$ & $1.18(1.05 \text { to } 1.33)^{\star \star}$ \\
\hline Birthweight & & \\
\hline 10-90th centile (ref) & & \\
\hline$<10$ th centile & 1.05 (0.83 to 1.34$)$ & 1.08 (0.88 to 1.32$)$ \\
\hline >90th centile & $0.92(0.73$ to 1.13$)$ & 0.96 (0.78 to 1.12$)$ \\
\hline
\end{tabular}

varied over the past decade. The prevalence of MS is lower when using definitions other than ATPIII; however, the risks of cardiovascular events, diabetes mellitus and hypertension are similar for ATPIII and American Heart Association (AHA) or International Diabetes Federation (IDF) definitions. ${ }^{28}$ Glycaemia was not recorded in the cohort study biomedical survey; therefore, we used the HbA1c value with a cut-off above $6.5 \%$ to define hyperglycaemia. HbAlc has been defined as a marker to identify diabetes status. ${ }^{29}$ The reliability of glucose measurements varies widely across laboratories and may result in misclassification of $>12 \%$ of patients. ${ }^{30}$ By contrast, HbAlc values are relatively stable after collection. ${ }^{31}$ The NCDS cohort provides a rare opportunity to study conditions and characteristics at birth and in early life collected prospectively, in relation to good quality biological data sampled in midlife. Unfortunately, no information was collected at the time about gestational diabetes; however, we include birthweight and variables on other pregnancy complications which may capture the effect of insulin resistance during pregnancy. It was possible to include a large number of potential confounding variables in the statistical models; however, it is possible that a key unknown confounding factor during early life was omitted, which might explain the differences observed in MS outcome between the mode of delivery groups.

\section{CONCLUSION}

These findings suggest that mode of delivery at birth may be an important variable to take into account to understand the aetiology of metabolic disorders. It is likely to represent factors occurring in the environment proximal to the birth which may have an impact on the baby's health across the lifecourse. Our findings show 
that in 1958, emergency caesarean sections may be associated with an increased prevalence of MS in midlife. We suggest that given the maternity practices of the time, physiological stress experienced by the baby during delivery may be an important mechanism in the subsequent development of metabolic disorders.

\section{Author affiliations}

${ }^{1}$ Service de Médecine Interne et HTA, CHU Rangueil, Toulouse, France

${ }^{2}$ INSERM UMR 1027, Toulouse, France

${ }^{3}$ Université Toulouse III, UMR1027, Toulouse, France

${ }^{4}$ Service d'Epidémiologie, CHU Toulouse, Toulouse, France

Acknowledgements The authors are grateful to the Centre for Longitudinal Studies (CLS), Institute of Education for the use of the National Child Development Study (NCDS) data and to the Economic and Social Data Service (ESDS) for making them available.

Contributors BB, VE and MK-I were involved in the conception and design of the study, as well as in analysing and interpreting the data, drafting the manuscript and making modifications. BB and VE contributed equally to the work. TL, $C D$ and $B C$ analysed and interpreted the analyses, and revised the manuscript. All authors approved the current version.

Funding MKI is funded by the Agence National de Recherche (grant number: RPV12021BBA).

Competing interests None.

Ethics approval National Research Ethics Advisory Panel.

Provenance and peer review Not commissioned; externally peer reviewed.

Data sharing statement No additional data are available.

Open Access This is an Open Access article distributed in accordance with the Creative Commons Attribution Non Commercial (CC BY-NC 3.0) license, which permits others to distribute, remix, adapt, build upon this work noncommercially, and license their derivative works on different terms, provided the original work is properly cited and the use is non-commercial. See: http:// creativecommons.org/licenses/by-nc/3.0/

\section{REFERENCES}

1. Huh SY, Rifas-Shiman SL, Zera CA, et al. Delivery by caesarean section and risk of obesity in preschool age children: a prospective cohort study. Arch Dis Child 2012;97:610-16.

2. Zhou L, He G, Zhang J, et al. Risk factors of obesity in preschool children in an urban area in China. Eur J Pediatr 2011;170:1401-6.

3. Menacker F, Hamilton BE. Recent trends in cesarean delivery in the United States. NCHS Data Brief 2010;35:1-8.

4. Ford ES, Giles WH, Dietz WH. Prevalence of the metabolic syndrome among US adults: findings from the third National Health and Nutrition Examination Survey. JAMA 2002;287:356-9.

5. Ley RE, Turnbaugh PJ, Klein S, et al. Microbial ecology: human gut microbes associated with obesity. Nature 2006;444:1022-3.

6. Bäckhed F, Ding $\mathrm{H}$, Wang $\mathrm{T}$, et al. The gut microbiota as an environmental factor that regulates fat storage. Proc Natl Acad $\mathrm{Sci}$ USA 2004;101:15718-23.

7. Cani PD, Amar J, Iglesias MA, et al. Metabolic endotoxemia initiates obesity and insulin resistance. Diabetes 2007;56:1761-72.

8. Karlsson FH, Tremaroli V, Nookaew I, et al. Gut metagenome in European women with normal, impaired and diabetic glucose control. Nature 2013;498:99-103.
9. Biasucci G, Benedati B, Morelli L, et al. Cesarean delivery may affect the early biodiversity of intestinal bacteria. $J$ Nutr 2008;138:1796S-800S

10. Salminen S, Gibson GR, McCartney AL, et al. Influence of mode of delivery on gut microbiota composition in seven year old children. Gut 2004:53:1388-9.

11. Grönlund MM, Lehtonen OP, Eerola E, et al. Fecal microflora in healthy infants born by different methods of delivery: permanent changes in intestinal flora after caesarean delivery. $J$ Pediatr Gastroenterol Nutr 1999;28:19-25.

12. Luoto R, Kalliomäki M, Laitinen $\mathrm{K}$, et al. Initial dietary and microbiological environments deviate in normal-weight compared to overweight children at 10 years of age. J Pediatr Gastroenterol Nutr 2011;52:90-5.

13. Zhang J, Troendle J, Reddy UM, et al. Contemporary cesarean delivery practice in the United States. Am J Obstet Gynecol 2010;203:326.e1-10.

14. Power C, Elliott J. Cohort profile: 1958 British Birth Cohort (National Child Development Study). Int J Epidemiol 2006;35:34-41.

15. Expert Panel on Detection, Evaluation, and Treatment of High Blood Cholesterol in Adults. Executive Summary of the Third Report of the National Cholesterol Education Program (NCEP) Expert Panel on Detection, Evaluation, and Treatment of High Blood Cholesterol in Adults (Adult Treatment Panel III). JAMA 2001;285:2486-97.

16. Royston P. Multiple imputation of missing values: further update of ice, with an emphasis on categorical variables. Stata $J$ 2009;9:466-77.

17. Holding back the tide of caesareans. BMJ 1988;297:852.

18. Alastalo $\mathrm{H}$, von Bonsdorff $\mathrm{MB}$, Räikkönen $\mathrm{K}$, et al. Early life stress and physical and psychosocial functioning in late adulthood. PLoS ONE 2013;8:e69011.

19. Kelly-Irving M, Lepage B, Dedieu D, et al. Adverse childhood experiences and premature all-cause mortality. Eur J Epidemiol 2013;28:721-34.

20. Chandola T, Brunner E, Marmot M. Chronic stress at work and the metabolic syndrome: prospective study. BMJ 2006;332:521-5.

21. Bennet R, Nord CE. Development of the faecal anaerobic microflora after caesarean section and treatment with antibiotics in newborn infants. Infection 1987;15:332-6.

22. Azad MB, Konya $\mathrm{T}$, Maughan $\mathrm{H}$, et al. Gut microbiota of healthy Canadian infants: profiles by mode of delivery and infant diet at 4 months. CMAJ 2013;185:385-94.

23. Boney CM, Verma A, Tucker R, et al. Metabolic syndrome in childhood: association with birth weight, maternal obesity, and gestational diabetes mellitus. Pediatrics 2005;115:e290-6.

24. Dabelea D, Mayer-Davis EJ, Lamichhane AP, et al. Association of intrauterine exposure to maternal diabetes and obesity with type 2 diabetes in youth: the SEARCH Case-Control Study. Diabetes Care 2008;31:1422-6.

25. Hillier TA, Pedula KL, Schmidt MM, et al. Childhood obesity and metabolic imprinting: the ongoing effects of maternal hyperglycemia. Diabetes Care 2007;30:2287-92.

26. Salonen MK, Kajantie E, Osmond C, et al. Childhood growth and future risk of the metabolic syndrome in normal-weight men and women. Diabetes Metab 2009;35:143-50.

27. Eriksson JG, Forsen TJ, Kajantie E, et al. Childhood growth and hypertension in later life. Hypertension 2007;49:1415-21.

28. Mancia G, Bombelli M, Facchetti R, et al. Impact of different definitions of the metabolic syndrome on the prevalence of organ damage, cardiometabolic risk and cardiovascular events. $J$ Hypertens 2010;28:999-1006.

29. International Expert committee. International Expert committee report on the role of the AIC assay in the diagnosis of diabetes. Diabetes Care 2009;32:1327-34

30. Miller WG, Myers GL, Ashwood ER, et al. State of the art in trueness and interlaboratory harmonization for 10 analytes in general clinical chemistry. Arch Pathol Lab Med 2008;132:838-46.

31. Little RR, Rohlfing CL, Tennill AL, et al. Effects of sample storage conditions on glycated hemoglobin measurement: evaluation of five different high performance liquid chromatography methods. Diabetes Technol Ther 2007;9:36-42. 